\title{
IDENTIFICATION OF CAUSATIVE FISH FOR A FOOD POISIONING IN TAIWAN BY USING SDS-PAGE TECHNIQUE
}

Tai-Yuan Chen

Institute of Biological Chemistry and Genomic Research Center, Academia Sinica, Taipei, Taiwan, R.O.C.

Nan-Hong Chen

Department of Food Science, National Taiwan Ocean University, Keelung, Taiwan, R.O.C

Wen-Feng Lin

Department of Food Science, National Taiwan Ocean University, Keelung, Taiwan, R.O.C

Ken-Lin Hwang

Department of Applied Life Science, Asia University, Taichung County, Taiwan, R.O.C.

Yun-Chieh Huang

Department of Food Science, National Taiwan Ocean University, Keelung, Taiwan, R.O.C

See next page for additional authors

Follow this and additional works at: https://jmstt.ntou.edu.tw/journal

Part of the Aquaculture and Fisheries Commons

\section{Recommended Citation}

Chen, Tai-Yuan; Chen, Nan-Hong; Lin, Wen-Feng; Hwang, Ken-Lin; Huang, Yun-Chieh; and Hwang, Deng-Fwu (2010) "IDENTIFICATION OF CAUSATIVE FISH FOR A FOOD POISIONING IN TAIWAN BY USING SDS-PAGE TECHNIQUE," Journal of Marine Science and Technology. Vol. 18: Iss. 4, Article 16.

DOI: $10.51400 / 2709-6998.1924$

Available at: https://jmstt.ntou.edu.tw/journal/vol18/iss4/16

This Research Article is brought to you for free and open access by Journal of Marine Science and Technology. It has been accepted for inclusion in Journal of Marine Science and Technology by an authorized editor of Journal of Marine Science and Technology. 


\section{IDENTIFICATION OF CAUSATIVE FISH FOR A FOOD POISIONING IN TAIWAN BY USING SDS-PAGE TECHNIQUE}

\section{Acknowledgements}

Fish species were identified by Dr. Hong-Ming Chen, Department of Aquaculture, National Taiwan Ocean University by using morphological analysis. This study was partly supported by National Science Council (NSC-96-2628-B-019-001- MY3)

\section{Authors}

Tai-Yuan Chen, Nan-Hong Chen, Wen-Feng Lin, Ken-Lin Hwang, Yun-Chieh Huang, and Deng-Fwu Hwang 


\title{
IDENTIFICATION OF CAUSATIVE FISH FOR A FOOD POISIONING IN TAIWAN BY USING SDS-PAGE TECHNIQUE
}

\author{
Tai-Yuan Chen*, Nan-Hong Chen**, Wen-Feng Lin**, Ken-Lin Hwang***, \\ Yun-Chieh Huang**, and Deng-Fwu Hwang**
}

Key words: grouper, ciguatera, food poisoning, SDS-PAGE, species identification.

\begin{abstract}
A food poisoning incident has occurred due to ingestion of red grouper meat on February 2006 in southern Taiwan. Two patients showed diarrhea, muscle weakness, vertigo and severe muscle pain. The 2 pieces of causative residues were investigated by toxicity assay. In order to identify the fish species of causative samples, sodium dodecyl sulfate-polyacrylamide gel electrophoresis (SDS-PAGE) technique was applied in this study. According to the low molecular weight region $(<30.0$ $\mathrm{kD})$ of species-specific patterns extracted from both myofibrillar and sarcoplasmic proteins, two poisoning samples were identified as Lutjanus bohar. L. bohar is a notorious grouper species with ciguatera in the world.
\end{abstract}

\section{INTRODUCTION}

Ciguatera is a food poison from tropical or subtropical coral reef fish. In the world, more than 25,000 persons estimated were affected by ciguatera every year. The distribution of ciguatera is confined to discrete regions of Pacific Ocean, western Indian Ocean and Caribbean Sea [14]. The ciguateric toxin, ciguatoxin (CTX), is produced by the toxin dinoflagellate Gambierbiscus toxicus, and they will be accumulated first in herbivorous fish and subsequently in carnivorous fish through the food chain [20]. While some people eat the toxic fish, it will cause food poisoning [5]. The causative fish seem to be limited to several definite coral reef fish, including red grouper, moray eel, doctor fish and toothed jobfish. In

Paper submitted 04/14/09; revised 07/21/09; accepted 08/25/09. Author for correspondence: Deng-Fwu Hwang (e-mail: dfhwang@mail.ntou.edu.tw).

*Institute of Biological Chemistry and Genomic Research Center, Academia Sinica, Taipei, Taiwan, R.O.C.

**Department of Food Science, National Taiwan Ocean University, Keelung, Taiwan, R.O.C.

***Department of Applied Life Science, Asia University, Taichung County, Taiwan, R.O.C.
Taiwan, only one death was reported among all poisoning cases. However, the real fish species are almost not identified, except 2004's outbreak caused by moray eel Gymnothoraz javanicus [24].

Groupers as genus Lutjanus are the commercially important fish species with high price in Taiwan. These fish distribute in the tropical and subtropical coral reef district in the world extensively and are carnivorous and edible important species [14]. Otherwise, the food poison incident occasionally occurred when people ate them. In Taiwan, there are more than 10 outbreaks happened. A food poisoning incident has occurred due to ingestion of red grouper meat on February 3, 2006 in Tainan, southern Taiwan. About 12 hr after eating, three patients showed the clinic symptoms of pricking of the lips, tongue and throat, vomiting, abdominal cramps, diarrhea, headache, dizziness, vertigo and paralysis. These symptoms are similar to those of ciguatera [9]. The toxicity and species of toxic fish samples implicated into ciguatera are less studied so far because of the causative residues lacked to retain for study and the morphological characteristics of retained residue have been removed.

Several official electrophoretic methods have been employed to differentiate species of seafood or seafood products [1]. Other feasible methods have been subsequently applied in identifying fish or shellfish species, including sodium dodecyl sulfate-polyacrylamide gel electrophoresis (SDS-PAGE), ureaisoelectric focusing (urea-IEF), high performance liquid chromatography (HPLC), capillary electrophoresis (CE), immunoassay, enzyme-linked immunosorbent assay (ELISA), and DNA techniques. Recent years, standardized methods of species identification for raw and heat-processed fish using SDS-PAGE and urea-IEF techniques have been established via collaborative studies [7, 19, 21, 23]. As previously reported [11], we have used DNA technique to identify the causative fish species as Lutjanus bohar. In this study, SDS-PAGE was used with Coomassie blue staining for visualizing protein bands. After comparing the species-specific protein band patterns, the species of causative grouper was identified as that of DNA technique. 
Table 1. Protein contents $(\mathrm{mg} / \mathrm{ml})$ of sarcoplasmic and myofibrillar extracts from different fish species muscle.

\begin{tabular}{lcc}
\hline Fish species & Sarcoplasmic protein & Myofibrillar protein \\
\hline Poisoning sample 1 (PS1) & $3.4 \pm 0.5^{*}$ & $5.1 \pm 0.3$ \\
$\quad$ Kaohsiung Chang-Gung Memorial Hospital & & \\
Poisoning sample 2 (PS2) & $3.1 \pm 0.8$ & $4.8 \pm 0.4$ \\
$\quad$ Tainan City Health Bureau) & $7.5 \pm 0.4$ & $11.2 \pm 1.4$ \\
Lutjanus bohar (LB) & $6.8 \pm 0.3$ & $8.3 \pm 0.3$ \\
Variola albimarginata (VA) & $5.3 \pm 0.3$ & $7.4 \pm 0.5$ \\
Cephalopholis sonnerati (CS) & $7.9 \pm 0.5$ & $10.3 \pm 0.7$ \\
Lutjanus gibbus (LG) & $10.1 \pm 1.1$ & $14.8 \pm 1.2$ \\
Acanthurus dussumieri (AD) & & \\
\hline
\end{tabular}

* Data are mean \pm S.D. of triplicate assays.

\section{MATERAILS AND METHODS}

\section{Materials}

The remaining uneaten frozen fish fillets with small viscera and skin were weighed (154 and $182 \mathrm{~g}$ ) and kept frozen below $-20^{\circ} \mathrm{C}$ until use. Three specimens of each species from 11 ciguatoxin-suspected fish were collected from Pingtung and Kaohsiung in South Taiwan during April to October 2006. These species of collected samples included Lutjanus bohar (LB), Variola albimarginata (VA), Cephalopholis sonnerati (CS), Lutjanus gibbus (LG), Acanthurus dussumieri (AD), Lutjanus sebae (LS), Lutjanus erythropterus (LE), Lethrinus olivaceus (LO), Lethrinus nebulosus (LN), Plectorhinchus vittatus (PV) and Plectorhinchus flavomaculatus (PF). All samples were immediately transferred on ice to the laboratory.

\section{Assay of Toxicity}

Each of all viscera and muscles in the causative residues and fresh specimens was heated at $70^{\circ} \mathrm{C}$ water bath for $15 \mathrm{~min}$, homogenized with 3 volume of acetone, and then centrifuged at $3,000 \times \mathrm{g}$ for $20 \mathrm{~min}$. The residue was repeated to extract two more times. All supernatants were combined, evaporated to free from acetone. The aqueous solution was added with the same volume of ethyl ether to extract toxin trice. The upper phase (ether phase) were combined and evaporated to dry out. The residue was dissolved with $90 \%$ methanol and extracted with two volumes of n-hexane twice. The $90 \%$ methanol part was evaporated to free from methanol and the residue was dissolved with $0.1 \%$ Tween 20 solution for mouse assay. The toxicity was calculated by formula as follows: $\log (\mathrm{MU})=2.3$ $\log (1+1 / T) . T(\mathrm{hr})$ is the survival time of $18-20 \mathrm{~g}$ ICR (Institute of Cancer Research) male mice after injection [15].

\section{Protein Extraction}

The extracts of fish sarcoplasmic and myofibrillar proteins were prepared according to the procedure described by Hashimoto et al. [10]. The 3 g sample was homogenized with 3 volumes of phosphate buffer ( $\mathrm{I}=0.05, \mathrm{pH} 7.5)$ for 1 min using a Polytron (setting 4.0, Kinenatica Ag Littau, Switzerland). The homogenate was centrifuged at $10,000 \times \mathrm{g}$ for $15 \mathrm{~min}$, using Himac CF15D2 with rotor RT15A6 (Hitachi, Japan).
Otherwise, $3 \mathrm{~g}$ sample was homogenized with 3 volumes of either $1 \% \operatorname{SDS}(\mathrm{w} / \mathrm{v})$ solution for $1 \mathrm{~min}$, using a polytron. All extracts were centrifuged at $10,000 \times \mathrm{g}$ for $15 \mathrm{~min}$ at $20^{\circ} \mathrm{C}$. The precipitate was similarly homogenized and centrifuged again. Both supernatants were separately combined and used as $1 \%$ SDS extract [19]. The protein concentration was determined by Lower method [16]. The protein extracts were adjusted with sample buffer to $2 \mathrm{mg} / \mathrm{ml}$ for Coomassie blue staining.

\section{SDS-PAGE Analysis}

SDS-PAGE was performed according to the modified procedure of Laemmli [12] and O'Farrell [18], using a MiniProtean unit (Bio-Rad, Richmond, Calif.). Slab gels consisted of a separating gel $(12.0 \%)$ and a stacking gel (4.0\%). Electrophoresis was carried out at a constant voltage of 80 volts initially and increased to 120 volts when the tracking dye reached the separating gel. Gels were stained with Coomassie blue reagent, $0.1 \%(\mathrm{w} / \mathrm{v})$ Coomassie blue R-250 in $40 \%$ methanol and $10 \%$ acetic acid. After staining, gels were destained in $10 \%$ methanol and $10 \%$ acetic acid. Molecular weights were determined by comparing relative mobility of protein bands to standard proteins [25]. The gels were scanned and the acquired images were analyzed with the Image Master VDS (Pharmacia Biotech). The molecular weights were estimated by comparing $R_{f}$ values on the gel with those of the protein standards. Statistical analysis for differences among the species was performed by the analysis of variance (ANOVA) procedure of Statistical Analysis System. The $p$ value $<0.05$ was considered statistically significant.

\section{RESULTS AND DISCUSSION}

After injecting with the extract of causative fish viscera, mice appeared diarrhea, breathing difficulty and then death. The toxicity of viscera was $2.45 \mathrm{MU} / \mathrm{g}$ (17.15 ng CTX/g) for sample 1 and $5.36 \mathrm{MU} / \mathrm{g}$ (37.52 ng CTX/g) for sample 2. The symptoms of mice injected with the extract from the muscle of causative samples and other species of ciguatoxin-suspected fish did not appear, so the toxicity of these tested samples was not detected. It means that the toxic ratio of related fish spe- 


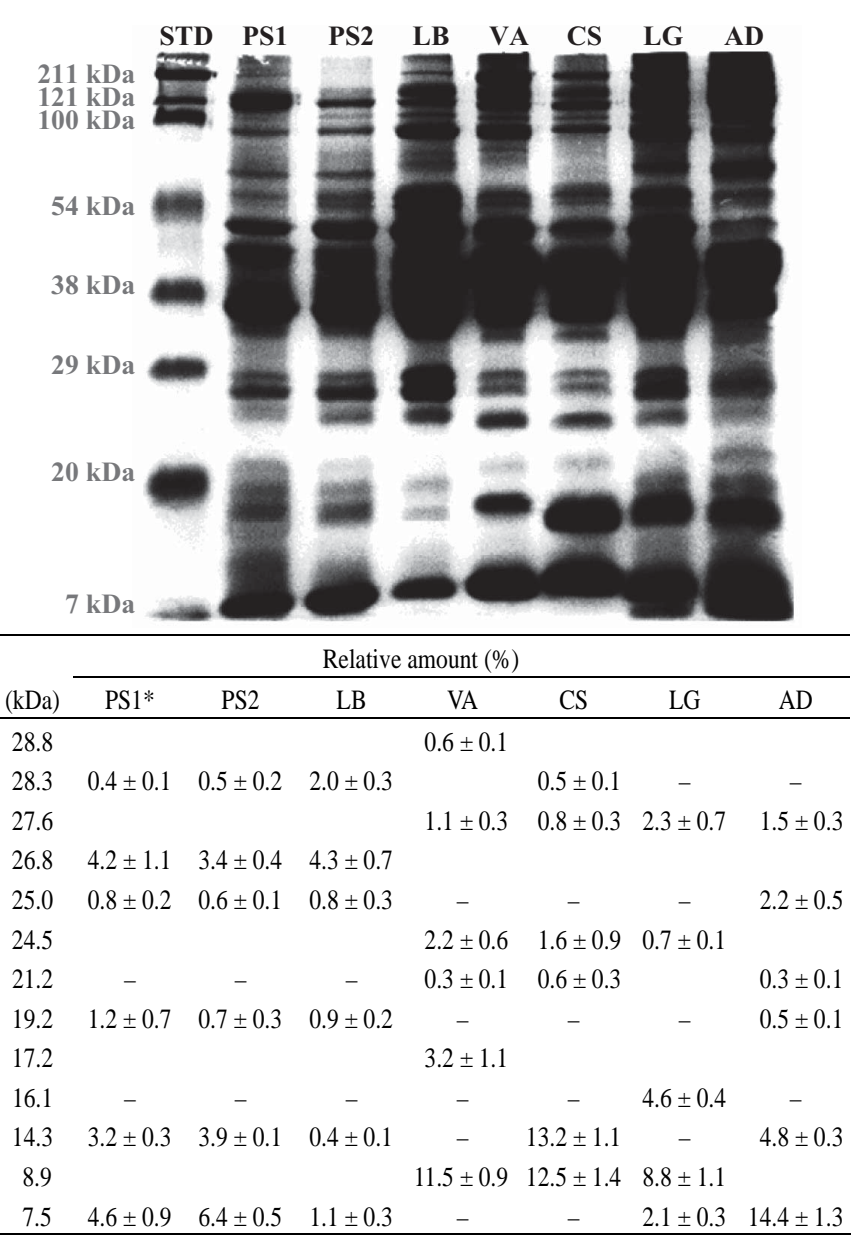

Fig. 1. SDS-PAGE patterns of sarcoplasmic proteins from different fish species with Coomassie blue staining and composition percentage of low molecular weight proteins $(n=3)$. STD: molecular standards, PS1: poisoning sample 1 (Kaohsiung Chang-Gung Memorial Hospital), PS2: poisoning sample 2 (Tainan Bureau of Health), LB: Lutjanus bohar, VA: Variola albimarginata, CS: Cephalopholis sonnerati, LG: Lutjanus gibbus, AD: Acanthurus dussumieri.

cies is not high in Taiwan and the toxicity may appear in the viscera when the fish become bigger. Previous researches pointed out that small size of coral reef fish usually do not contain toxicity $[2,8]$, and the content of ciguatoxin accumulated in viscera was more than in muscle [13].

After muscle extracting from 2 causative specimens and 5 ciguatoxin-suspected fish samples, protein extractability is shown in Table 1. The concentration of protein extracted from fish tissue represented the fresh degree and muscle quality in each sample. The protein concentration of the myofibrillar protein extracts was higher than that of the sarcoplasmic protein extracts in this study. Judging from the high molecular weight region ( $\geqq 30.0 \mathrm{kD}$ ) of both myofibrillar and sarcoplasmic protein extracts with Coomassie blue staining, there was no species-specific protein band among these investigated specimens (Figs. 1, 2). The bands of high molecular weight region ( $\geqq 30.0 \mathrm{kD}$ ) were apparently not useful in identifying fish species in this study.

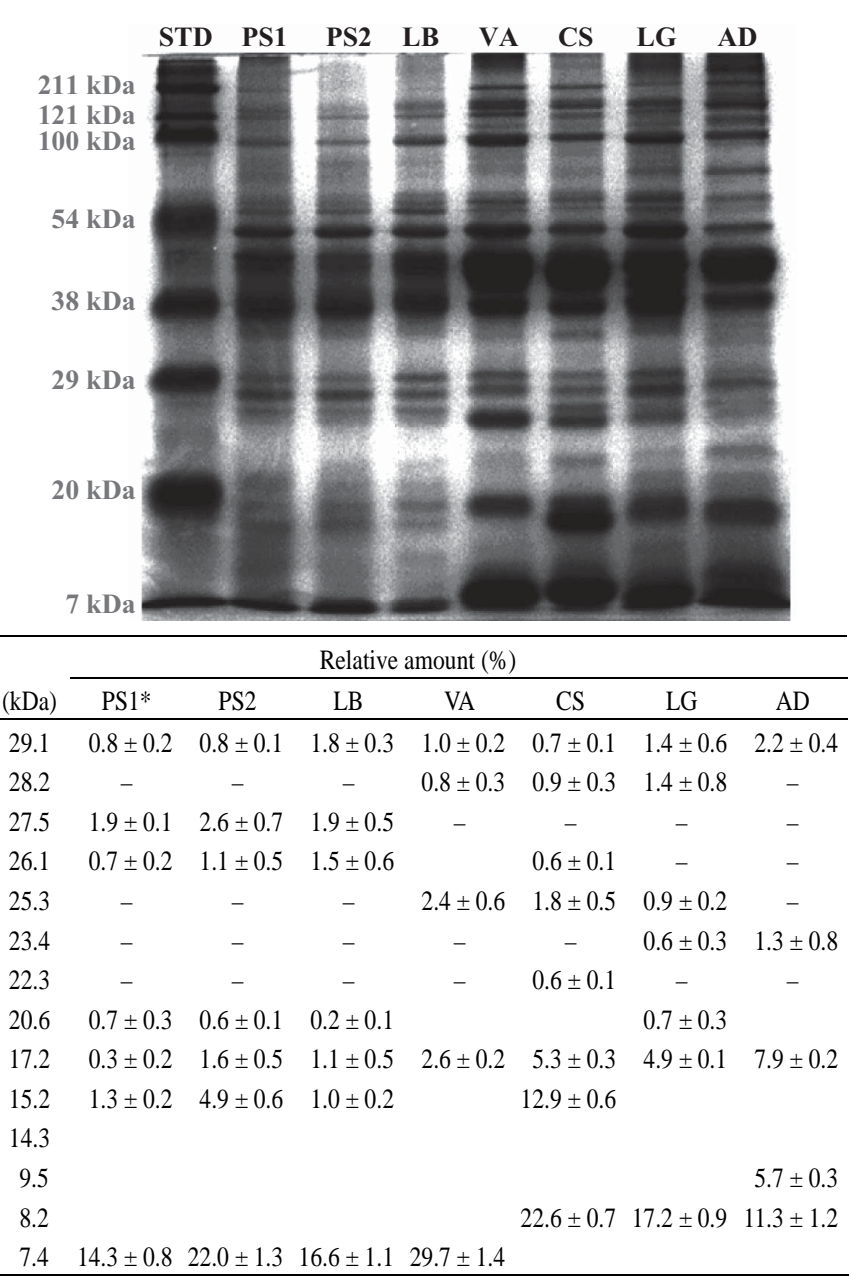

Fig. 2. SDS-PAGE patterns of myofibrillar proteins from different fish species with Coomassie blue staining and composition percentage of low molecular weight proteins $(n=3)$. The Symbols refer to authentic species and the footnote detailed in Fig. 1.

SDS-PAGE pattern of sarcoplasmic proteins extracted with phosphate buffer following Coomassie blue staining and the densities of the low molecular weight protein bands are shown in Fig. 1. In the low molecular weight region $(<30.0 \mathrm{kD})$ of sarcoplasmic proteins, specific bands were observed in each species. Therefore, species of 5 tested fish could be identified by using $7.5 \mathrm{kD}$ to $28.8 \mathrm{kD}$ protein bands. The characteristic protein bands of these 5 species were respectively as follows: $28.3,26.8,25.0,19.2,14.3$ and $7.5 \mathrm{kD}$ for $\mathrm{LB} ; 28.8,27.6,24.5$, $21.2,17.2$ and $8.9 \mathrm{kD}$ for $\mathrm{VA} ; 28.3,27.6,24.5,21.2,14.3$ and 8.9 kD for CS; 27.6, 24.5, 16.1, 8.9 and 7.5 kD for LG; 27.6, 25.0, 21.2, 19.2, 14.3 and $7.5 \mathrm{kD}$ for AD. Otherwise, the specific bands in both PS1 and PS2 were 28.3, 26.8, 25.0, 19.2, 14.3 and $7.5 \mathrm{kD}$. The patterns of low molecular weight region $(<30.0 \mathrm{kD})$ of sarcoplasmic proteins extracted from 2 causative specimens were totally the same as the pattern in LB.

In the low molecular weight region $(<30.0 \mathrm{kD})$ of myofibrillar proteins, a number of bands were presented by composition of myosin light chains, troponins and parvalbumins. 
The pattern of low molecular weight region $(<30.0 \mathrm{kD})$ of myofibrillar proteins extracted by phosphate buffers also shows the specific bands from each species (Fig. 2). Inspection of the $7.4 \mathrm{kD}$ to $29.1 \mathrm{kD}$ protein band region displays the characteristic bands for these 5 species as follows: 29.1, 27.5, 26.1, 20.6, 17.2, 15.2 and 7.4 kD for $\mathrm{LB} ; 29.1,28.2,25.3,17.2$ and $8.2 \mathrm{kD}$ for VA; 29.1, 28.2, 26.1, 25.3, 22.3, 17.2, 15.2 and $8.2 \mathrm{kD}$ for CS; 29.1, 28.2, 25.3, 23.4, 20.6, 17.2 and $8.2 \mathrm{kD}$ for LG; 29.1, 23.4, 17.2, 9.5 and $8.2 \mathrm{kD}$ for AD. The specific bands in both PS1 and PS2, including 29.1, 27.5, 26.1, 20.6, 17.2, 15.2 and $7.4 \mathrm{kD}$, were also the same with that in LB.

According to the low molecular weight region $(<30.0 \mathrm{kD})$ of both myofibrillar and sarcoplasmic pattern, two poisoning samples (PS1 and PS2) were identified as Lutjanus bohar. The result reveals that species identification could be achieved by using SDS-PAGE analysis. In many reports also indicated that the characteristic protein bands could be extracted by SDScontaining solution and were usable for species identification $[3,4,6,22]$.

Up to the present, there was still no reliable prevention against ciguatoxin poisoning. It was suggested that the weight of coral reef fish should be less than $1.0 \mathrm{~kg}$ for diet. Furthermore, the viscera from coral reef fish are not allowed for eating [17]. In this study, the species of causative grouper is successfully identified as L. bohar. This grouper is a notorious species of ciguatera in the world because of causing food poisoning usually. For guaranteeing editable safety of grouper, the toxicity of $L$. bohar needs to be investigated in Taiwan.

\section{ACKNOWLEDGMENTS}

Fish species were identified by Dr. Hong-Ming Chen, Department of Aquaculture, National Taiwan Ocean University by using morphological analysis. This study was partly supported by National Science Council (NSC-96-2628-B-019-001MY3).

\section{REFERENCES}

1. AOAC, Official Methods of Analysis, $15^{\text {th }}$ ed, Association of Official Analytical Chemists, Arlington, VA (1990).

2. Brusle, J., Ciguatera Fish Poisoning: A Review, Sanitary and Economic Aspects. Les Editions INSERM, Paris (1997).

3. Chen, T. Y. and Hwang, D. F., "Electrophoretic identification of muscle proteins in 7 puffer species," Journal of Food Science, Vol. 67, pp. 936942 (2002)

4. Chen, T. Y., Shiau, C. Y., and Hwang, D. F., "Electrophoretic identification of muscle proteins in several puffer species with Coomassie blue/ silver staining," Fisheries Science, Vol. 69, pp. 1327-1330 (2002).

5. Colman, J. R., Dechraoui, M. Y. B., Dickey, R. W., and Ramsdell, J. S., "Characterization of the developmental toxicity of Caribbean ciguatoxins in finfish embryos," Toxicon, Vol. 44, pp. 59-66 (2004).

6. Craig, A., Ritchie, A. H., and Mackie, I. M., "Determining the authenticity of raw reformed breaded scampi (Nephrops norvegicus) by electrophoretic techniques," Food Chemistry, Vol. 52, pp. 451-454 (1995).

7. Etienne, M., Jerome, M., Fleurence, J., Rehbein, H., Kundiger, R., Yman, I. M., Ferm, M., Craig, A., Mackie, I. M., Jessen, F., Smelt, A., and Luten, J., "A standardized method of identification of raw and heat-processed fish by urea isoelectric focusing: A collaborative study," Electrophoresis, Vol. 20, pp. 1923-1933 (1999).

8. Guzman-Perez, S. E. and Park, D. L., "Ciguatera toxins: chemistry and detection," In: Botana, L. M. (ed.), Seafood and Freshwater Toxins: Pharmacology, Physiology and Detection, Marcel Dekker, New York, pp. 401-418 (2000).

9. Hashimoto, K. and Noguchi. T., "Recent studies on paralytic shellfish poison in Japan," Pure and Applied Chemistry, Vol. 61, pp. 7-18 (1989).

10. Hashimoto, K., Watabe, S., Kono, M., and Shiro, K., "Muscle protein composition of sardine andmackerel," Bulletin of the Japanese Society of Scientific Fisheries, Vol. 45, pp. 1435-1441 (1979).

11. Hsieh, C. H., Hwang, K. L., Lee, M. M., Lan, C. H., Lin, W. F., and Hwang, D. F., "Species identification of ciguatoxin-carrying grouper implicated in food poisoning," Journal of Food Protection, in press (2009).

12. Laemmli, U. K., "Cleavage of structural proteins during the assembly of the head of bacteriophage T4," Nature, Vol. 227, pp. 680-685 (1970).

13. Lewis, R. J., "Ciguatera: Australian perspectives on a global problem," Toxicon, Vol. 48, pp. 799-809 (2006).

14. Lewis, R. J., "The change face of ciguatera," Toxicon, Vol. 39, pp. 97-106 (2001).

15. Lewis, R. J., Sellin, M., Poli, M. A., Norton, R. S., Macleod, J. K., and Sheil, M. M., "Purification and characterization of ciguatoxin from moray eel (Lycodonits javaincus, Muraenidae)," Toxicon, Vol. 29, pp. 1115-1127 (1991).

16. Lowey, O. H., Rosebrough, N. J., Farr, A. L., and Randall, R. J., "Protein measurement with the Folin phenol reagent," Journal of Biological Chemistry, Vol. 193, pp. 265-275 (1951).

17. Lucas, R. E., Lewis, R. J., and Taylor, J. M., "Pacific ciguatoxin-1 associated with a large common-source outbreak of ciguatera in East Arnhem Land," Natural Toxins, Vol. 5, pp. 136-140 (1997).

18. O'Farrell, P. H., "High resolution two-dimensional electrophoresis of proteins," Journal of Biological Chemistry, Vol. 250, pp. 4007-4021 (1975).

19. Pineiro, C., Barros-Velazquez, J., Perez-Martin, R. I., Martinez, I., Jacobsen, T., Rehbein, H., Kundiger, R., Mendes, R., Etienne, M., Jerome, M., Craig, A., Mackie, I. M., and Jessen, F., "Development of sodium dodecyl sulfate - polyacrylamide gel electrophoresis reference method for the analysis and identification of fish species in raw and heatprocessed samples: A collaborative study," Electrophoresis, Vol. 20, pp. 1425-1432 (1999).

20. Poli, M. A., Lewis, R. J., Dickey, R. W., Musser, S. M., Buckner, C. A., and Carpenter, L. G., "Identification of Caribbean ciguatoxins as the cause of an outbreak of fish poisoning among U.S. solders in Hiti," Toxicon, Vol. 35, pp. 733-741 (1997).

21. Rehbein, H., Etienne, M., Jerome, M., Hattula, T., Kundsen, L. B., Jessen, F., Luten, J. B., Bouquet, W., Mackie, I. M., Ritchie, A. H., Martin, R., and Mendes, R., "Influence of variation in methodology on the reliability of the isoelectric focusing method of fish species identification," Food Chemistry, Vol. 52, pp. 193-197 (1995).

22. Rehbein, H., Kundiger, R., Yman, I. M., Ferm, M., Etienne, M., Jerome, M., Craig, A., Mackie, I., Jessen, F., Martinez, I., Mendes, R., Smelt, A., Luten, J., Pineiro, C., and Perez-Martin, R., "Species identification of cooked fish by urea isoelectric focusing and sodium dodecyl sulfate polyacrylamide gel electrophoresis: A collaborative study," Food Chemistry, Vol. 67, pp. 333-339 (1999).

23. Sotelo, C. G., Pineiro, C., Gallardo, J. M., and Perez-Martin, R. I., "Fish species identification in seafood products," Trends in Food Science and Technology, Vol. 4, pp. 395-401 (1993).

24. Tsai, W. L., Chen, H. M., Hsieh, C. H., Lin, W. F., and Hwang, D. F., "A potential methodology for differentiation of ciguatoxin-carrying species of moray eel," Food Control, Vol. 20, No. 6, pp. 575-579 (2009).

25. Weber, K., Pringle, J. R., and Osborn, M., "Measurement of molecular weights by electrophoresis on SDS-acrylamide gel," Methods in Enzymology, Vol. 26, pp. 3-27 (1972). 